\title{
Semiotic Analysis in Space and Communication
}

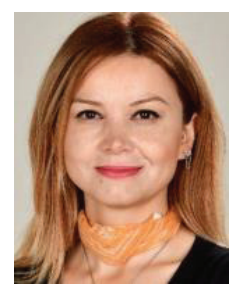

Gamze Akbaş

İstanbul Kültür University

Department of Interior Architecture

g.akbas@iku.edu.tr

\begin{abstract}
Semiotics, in its most general definition, is a way of understanding or interpretation of any concept, situation, or object. Semiotics is accepted as a discipline that helps us to communicate with the world we live in and helps us question messages that enable us to produce meaning. In this study, space reading is analyzed over semiotics concepts through the relationship established between architecture and semiotics. With this method, the concept to be defined is laid through "sign", "signifier" and "signified" elements; the examples of space, which constitute a meaningful whole in time, are discussed with an approach that proceeds on the terms "denotation" and "connotation". In this context, in the study, while focusing on the design elements through the terms "sign-signifier-signified", the answer to the references to the said design is searched with the term "connotation".
\end{abstract}

Keywords: Semiology, Architectural Design, Communication

\section{Mekân ve İletişimde Semiyotik Söylem}

Öz: Göstergebilim en genel tanımıla herhangi bir kavramı, bir durumu ya da nesneyi anlama ya da anlamlandırma biçimidir. Göstergebilim, yaşadığımız dünya ile iletişim kurmamızı sağlayan ve anlam üretmemize olanak sağlayan mesajları sorgulamamıza yardımcı olan bir disiplin olarak kabul edilmektedir. Bu çalışmada, mimarlık ve göstergebilim arasında ilişki kurularak, mekân okuması göstergebilim kavramları üzerinden analiz edilmektedir. Bu metot ile tanımı yapılacak kavram "gösterge", "gösteren" ve "gösterilen" öğeleri üzerinden gerçekleşmektedir; ayını zamanda, anlamlı bir bütün oluşturan mekân örnekleri "düzanlam" ve "yananlam" terimleri üzerinden ilerleyen bir yaklaşımla ele alınmaktadır. Bu bă̆lamda çalışmada, "gösterge-gösteren-gösterilen” terimleri aracıllğıyla tasarım öğelerine odaklanırken, "yananlam” terimiyle söz konusu tasarıma yapılan göndermelerin yanıtı aranmaktadır.

Anahtar Kelimeler: Göstergebilim, Mimari Tasarım, İletişim

\section{INTRODUCTION}

In this study, using semiology, semiotics as a method, its place and importance in space and communication are questioned. Although, in the most general sense, semiotics is a method that "replaces" or "represents" an asset, it evolves with the meanings that the individual or society attributes to a certain concept (object, state, etc.). Every meaning is created through the "coding" and "grouping" of the concept. Conducting the message to be given to the receiver (reader) with "encoded" information is related to semiotic analysis. Semiotics, which enables us to produce meaning for all the assets around us, gives us opportunity to find messages that exist behind what is seen. For this reason, the basic concepts of semiotics (syntax, sequence, sign, signifier, signified, denotation, connotation) and field of application (architecture, art, literature, advertisement, caricature etc.) should be known and the meanings attributed to a visual culture should be re-evaluated (Figure 1).

Doi Num : 10.17932/IAU.ARCH.2015.017/arch_v05i2004 


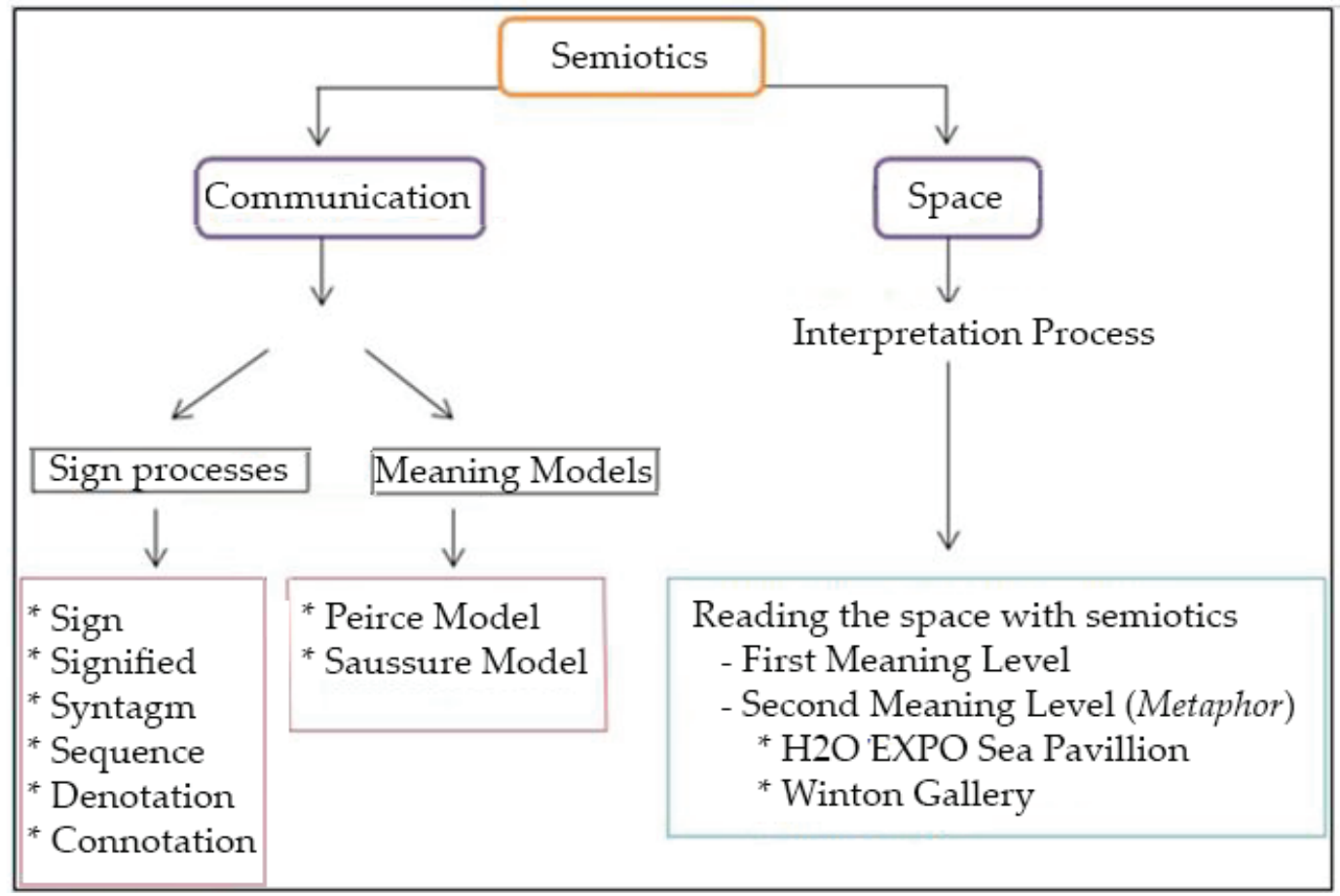

Figure 1. Scope of the research (created by the author)

"Sign" is at the focal point of semiotics and the state of "replacing" or "representing" something and it becomes an image that occurs in our minds. In other words, while the signs are not a concept or an asset itself, it is defined as a unit that evokes that thing $[1,2]$. In order to interpret the message sent to the other party, the individual needs prior knowledge (life experience) to read and make sense of the sign in question. Therefore, "signs" are defined through "groups" that help connect concepts and organize information.

\section{SEMIOTICS: BASIC CONCEPTS}

Under this heading, the terms "sign-signifier-signified", "syntax-sequence", "denotation-connotation" that enables an asset to be analyzed by the semiotics method, are considered as subtitles.

\subsection{Sign, Signifier and Signified}

A sign is a communication operation that represents or implies a "thing" (an object, a word, etc.). This communication operation has three special features. These are;

- Having a physical form,

- Referencing to something other than itself,

- Being accepted and used by the individual as a sign [3].

As linguistic and non-linguistic, the sign is classified in two ways. The linguistic sign is a communal communication system and examines the functioning of the language by basing it on social systems. Nonlinguistic signs, on the other hand, relate metaphor meaning concepts between the sender / receiver. If we give an example to this issue, "envelope" was considered as a sign of communication in ancient times. In this sense, the envelope format is used as the symbol of e-mail today, as its place in public life is to communicate / provide information. Pierre Guiraud (1994) clarifies this situation as follows: 
"The sign is a stimulus - that is, an emotional essence -. The memory image it evokes is connected to the image of another stimulus in our head. The function of the sign is to revive this second image in the direction of communication." [4].

In the field of semiotics, the concept of sign is represented through "signifier" and "signified". In the basic analysis method of the sign, while "signifier" is a concrete entity; the thought to be conveyed is considered as "signified". In the interpretation process of the sign, "signifier" has a material (concrete) entity and is the state before it is given a meaning [3]. Signified is expressed as a message (meaning or thought) to be transmitted to the other party. Therefore, in semiotic analysis, signified is accepted as "what the sign refers to" and the signifier shows "physical presence of the sign" [5] [6] . In this process, the signifier (an object, a word, etc.) sends a number of messages to the recipient through the signified; in this context, since the signifier is accepted as the physical condition of the sign, it becomes meaningful with the signified. The sign works as a communication tool for the recipient to sense and interpret these messages. This process is regarded as the first level of sense-making (Figure 2).

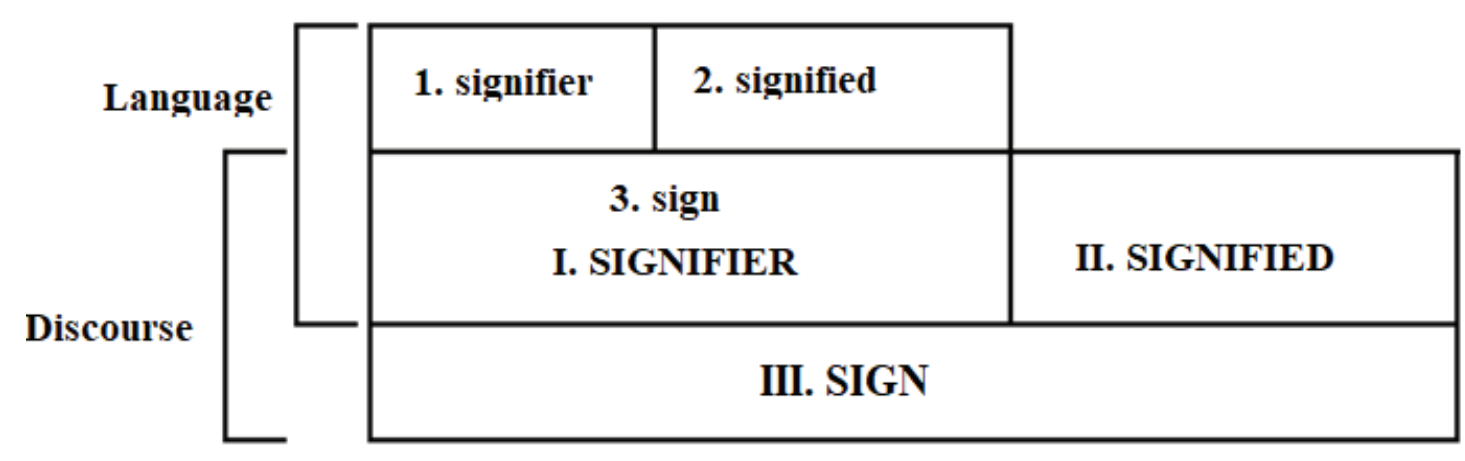

Figure 2. The process of sense-making [7]

\subsection{Syntagm and Sequence}

Syntagm, as Barthes stated (1979), is a process that takes place in the form of a sequence chain; in this context, the flow of the word is an example to the syntagm [8]. To create a meaningful whole, the connection of one unit to another is called syntagm. The following can be an example for syntagm (Fiske, 2014);

- a word formed by selecting the letters of the alphabet,

- choices made from paradigms such as hat, tie, shirt, jacket, socks made from clothes,

- a room designed by choosing from paradigms such as chair, table, carpet, wallpaper etc.

- a customer ordering an order by looking at the food list [9].

Therefore, it creates a set sequence composed of different architectural elements to define a space. It is possible for the sign to work in harmony with the help of a sequence. In other words, we can see that the sequence is exemplified through the "traffic lights paradigm" when the effect of the sequence on the interpretation process is taken into consideration (Figure 3). 


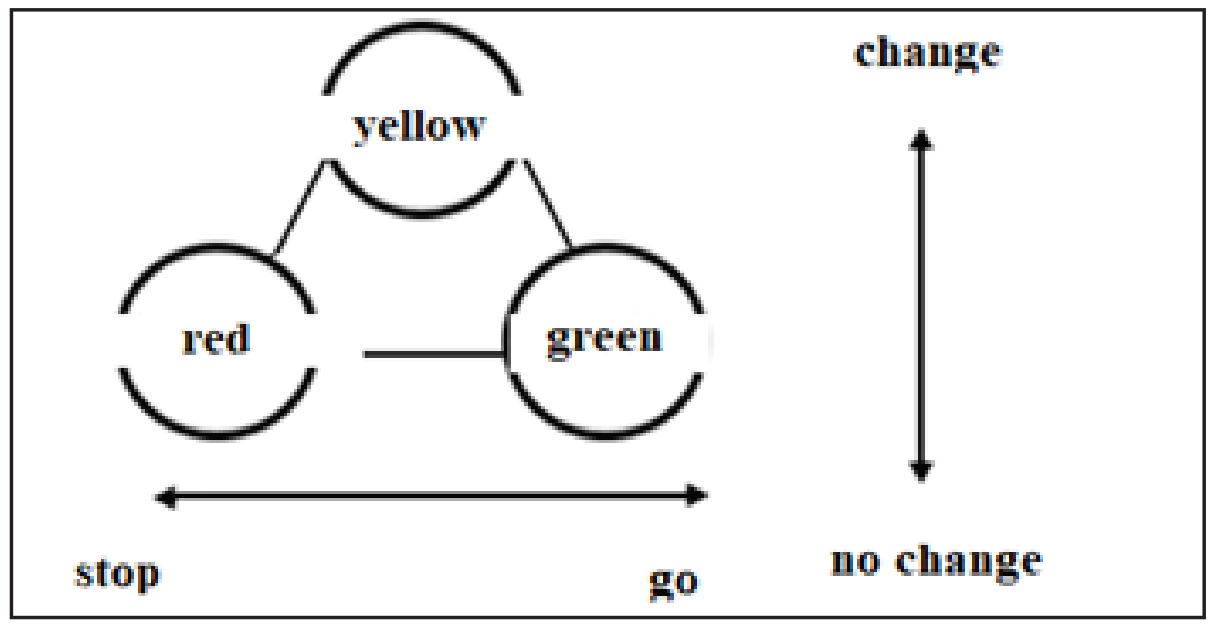

Figure 3. Sequence of traffic lights [9]

Red that signs danger means "stop" in the formal arrangement of traffic light. In the visual sign, we see that the color red has meanings such as danger, warning, threat, and anger; therefore, we can deduce that the "stop" sign is expressed in red light. Fiske (2014) says that the remaining colors will follow this flow in a logical order; Therefore, the author who draws attention to green, which is the opposite of red in the chromatic spectrum, defines the command "go" in this syntagm [9]. These features are important in terms of the roles given to concepts in communication. Since the harmony of red, yellow and green lights with each other has a meaning in itself and forms a sequence, it is also necessary to mention briefly the opposite colors in the chromatic spectrum: "Red-Green", "Yellow-Purple", "Orange-Blue". In summary, the signs that enable us to communicate form a paradigmatic group through syntagm, and functionally compatible units come together to define the sequence. In order to clarify this definition more, examples of different paradigms are presented in Table 1 and the difference between syntax and string is tried to be explained.

Table 1. Syntagm and Sequence [10]

\begin{tabular}{|l|l|l|}
\hline Clothe & \multicolumn{1}{|c|}{ Sequence } & \multicolumn{1}{c|}{ Syntagm } \\
\hline Food & $\begin{array}{l}\text { Pieces, additional parts or groups of details } \\
\text { that cannot be found at the same point of } \\
\text { the body at the same time, and of which } \\
\text { change leads to a change in clothing } \\
\text { meaning: beret/hat, etc. }\end{array}$ & $\begin{array}{l}\text { Having different items in the same } \\
\text { clothing side by side: Skirt, blouse, } \\
\text { jacket. }\end{array}$ \\
$\begin{array}{l}\text { A group of foods that offer similarities and } \\
\text { differences and that a food is selected in } \\
\text { relation to a particular meaning: Entree } \\
\text { food, fries or deli products. }\end{array}$ & $\begin{array}{l}\text { The real chain of dishes chosen } \\
\text { throughout the meal: It is a menu. }\end{array}$ \\
\hline Furniture & $\begin{array}{l}\text { A group composed of stylistic changes of } \\
\text { the same furniture (a bed). }\end{array}$ & $\begin{array}{l}\text { Bringing different furniture items side } \\
\text { by side in the same space (bed, } \\
\text { wardrobe, table, etc.) }\end{array}$ \\
\hline Architecture & $\begin{array}{l}\text { The diversity of one of the elements in a } \\
\text { structure in terms of style; different } \\
\text { housetop, balcony, entrance, etc. formats. }\end{array}$ & $\begin{array}{l}\text { The interconnection of details within } \\
\text { the entire structure. }\end{array}$ \\
\hline
\end{tabular}




\subsection{Denotation and Connotation}

The denotation of the sign is the first level of communication we know from our life experiences; therefore, it is the first image that occurs in our minds. Considered as the first level of interpretation by Barthes (1979), the denotation represents the concepts we know thanks to our prior knowledge. Since this level is expressed as an unencrypted image in a sense, it becomes the first concept in our mind to evoke in the sender/receiver relationship. If the connotation solid is a metaphorized state of being; as it is considered as the encrypted image plane, it is defined as the level of meaning that refers to a concept. On the other hand, Barthes (1979) expresses connotation as the second level of interpretation [8]. Erkman Akerson (2005) approaches the place of connotation in semiotics analysis as follows:

"For the creation of the connotation, it should not be completely disconnected from the denotation but should refer to some features in the denotation. The phenomenon of connotation is especially important in works of art and literature, even we can say that those are what make art as art." [1].

This is also accepted as the main level at which and sign becomes meaningful. Connotation is, in a sense, "mental representations", cultural values and the level of communication that becomes meaningful in a society with its attitudes.

\section{MEANING MODELS OF SEMIOTICS}

We see that Charles Sanders Peirce, a philosopher from USA and Swiss linguist Ferdinand de Saussure are the two leading names in studies on semiotics' meaning models.

\subsection{Charles Sanders Peirce Model}

Peirce, which enabled semiotics to become an independent field of science, equates this field, which he defined as "formal teaching of signs", with "logic" [11]. According to Peirce, meaning models are built according to triple distinctions (Figure 4). When we consider the sign / object / interpreter relationship that Peirce approaches in three planes, we see that there is a clear link between the "sign" that represents something and the "object" that equals to it. Establishing this relationship is possible with cognition patterns that develop with individual and cultural knowledge and through behavior patterns that develop with knowledge. In other words, the interpretation of the connection between the "sign" (with the representative) and the "object" (represented) takes place through the use of information stored in the mind.

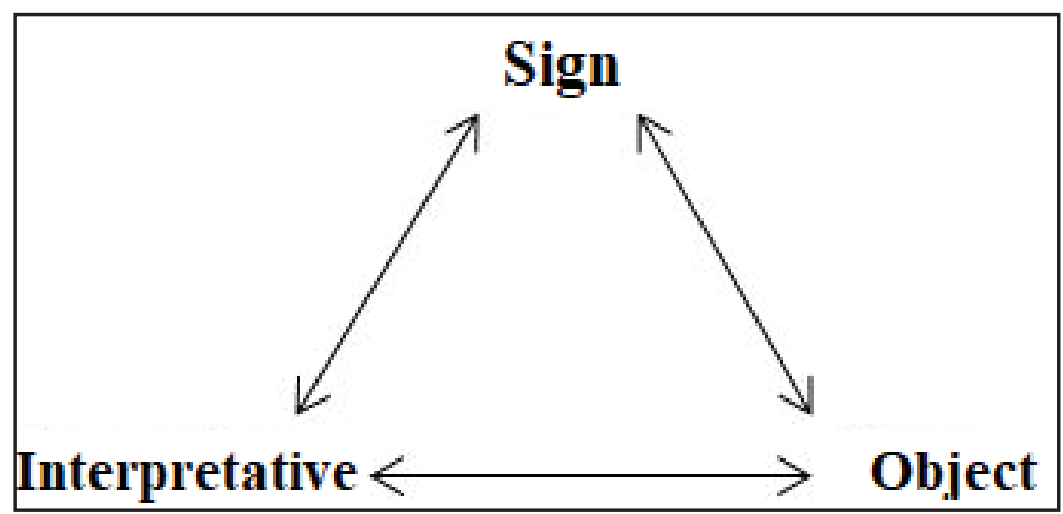

Figure 4. Peirce's semiotics elements [9]

The visual sign (icon) / indication / symbol are another important triple distinction of Peirce (Figure 5). Based on Peirce's expressions, we can explain the concept of this trio as follows; 
- Visual sign (icon); directly representing something somebody states (photographs, pictures, etc.),

- Indication; a true association between the two elements (smoke evokes fire, that is, being a "indication" of fire)

- Symbol; when there is no accord process between people, the disappearance of the situation that makes itself a sign (words, formulas in the field of mathematics or chemistry, the scale figure symbolizing justice and etc.) [12].

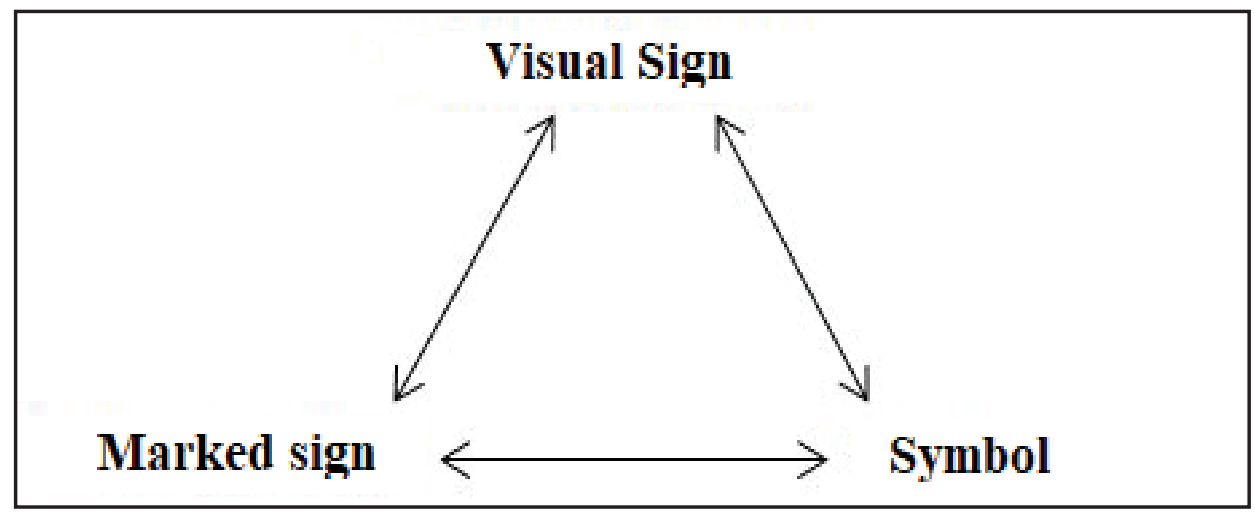

Figure 5. Peirce's sign types category [9]

\subsection{Ferdinand de Saussure}

"General Linguistics Lessons", which were published as a result of the gathering of students' lecture notes in general linguistics courses at the University of Geneva, of Saussure, is of great importance in the development of semiotics. Saussure (2001) bases the definition of language in semiotics on social sequences such as the alphabet, deaf-mute alphabet, sign of subtlety, and forms of behavior:

"... a science can be designed to examine the life of the signs in the community life: a science to be connected to social psychology, and consequently to general psychology. We will call it semiotics (Fr. semiologie <Yun. Semeion from 'sign'). Semiotics will teach us what the signs are and what laws they are connected to. There is no such science yet; so we can't say what semiotics will look like. But it needs to be established; its place is clear in advance. Linguistics is nothing more than part of this general quality science. Therefore, the laws that semiotics will find can be applied to linguistics. Thus, linguistics can be connected to a well-defined field within the whole of human facts." [13].

Saussure directly correlates the "concept" and "communication image", which he describes as a sign as a whole, because it treats the formation of a concept as a mental process. He evaluates this situation in a binary structure as "signifier" (image of hearing) and "signified" (concept). Mental phenomena called concepts are expressed abstractly; however, this abstract expression, which is intended to be transmitted to the other side, turns into sound waves and becomes a concrete (physical) state (Figure 6). 


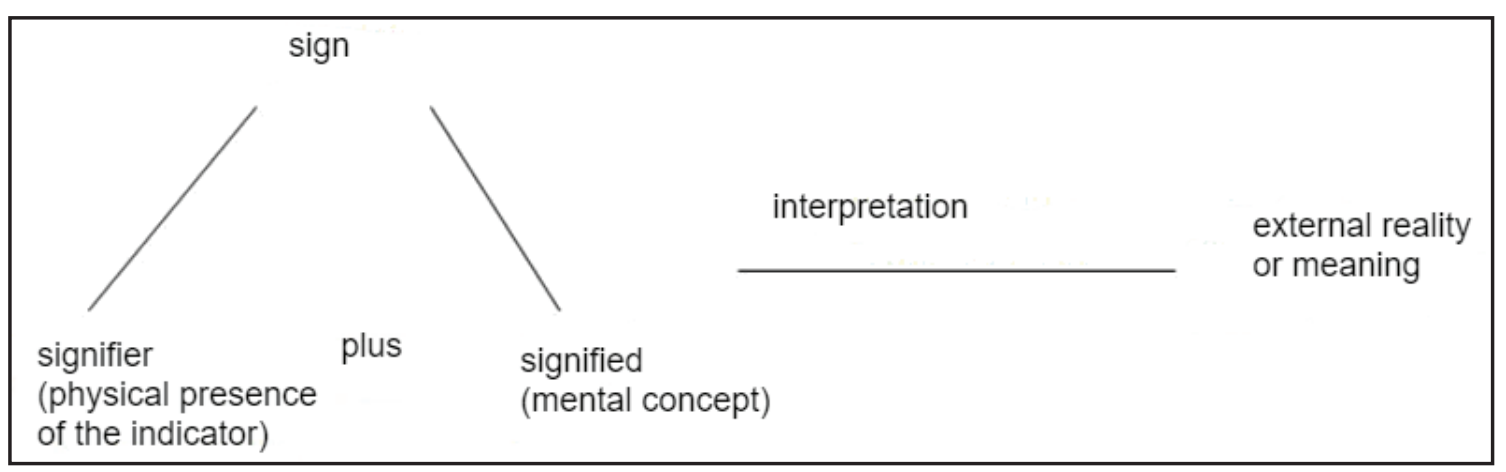

\section{Figure 6. Saussure's signification elements [9]}

In short, Saussure builds the linguistic sign on the receiver-transmitter:

- The sender expresses the concept in the mind by creating sound waves

- The receiver detects and responds to sound waves (sound chains) [1].

The ability of the buyer to understand and interpret a concept is closely related to cultural accumulation. The mother tongue and concept relationship of the individual pointed out by Saussure is handled through the tree. Saussure (2001), who searched for the meaning of the word "arbor" used to express the concept of tree in Latin, clarifies the subject as "we only see that the approximations approved by the language are in line with reality and push any other approximation that can be designed aside." (Figure 7) [13].

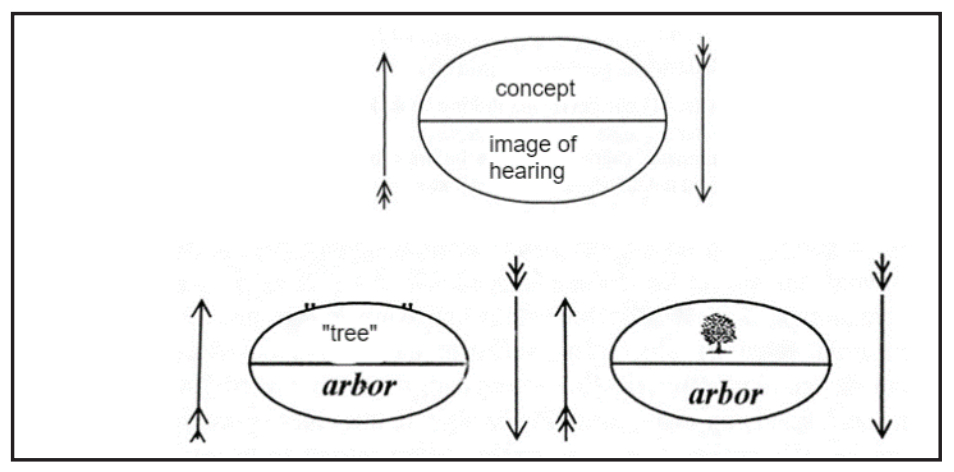

Figure 7. Hearing and concept image [13]

In other words, "cultural codes" that connect the concepts and are defined as mental representations that are met in a common denominator in a society have an effect on the buyer. Therefore, the "common values" of the people of the same culture create similarly thought and perceived "cultural codes" and provide a link between the concept and the image of hearing.

\section{READING OF THE SPACE BY THE SEMIOTICS METHOD}

Architectural products are used as a language tool in communication studies since they contain meanings and carry cultural values. In this part of the study, design studies are based on the semiotics method and space reading is done through the perception of form. Through this relationship, the architectural elements are separated as "sign", "signifier" and "signified", and the message that is intended to be given in the interior is interpreted. 
Following a brief reading on the theoretical framework of semiotics, architectural approaches are handled with a number of examples. H2O Expo Water Pavilion is one of the best designs we will show as an example in this regard. H2O Expo Water Pavilion is a structure designed based on the concept of liquid architecture and has hybrid features. Since the form of the structure is compared to an organism and is associated with the sea (a whale hitting the shore), it is representative of an abstract concept (Figure 8). While it gives visitors the feeling of being a part of the water, it creates a contrast by creating a virtual environment in a remarkable interior.
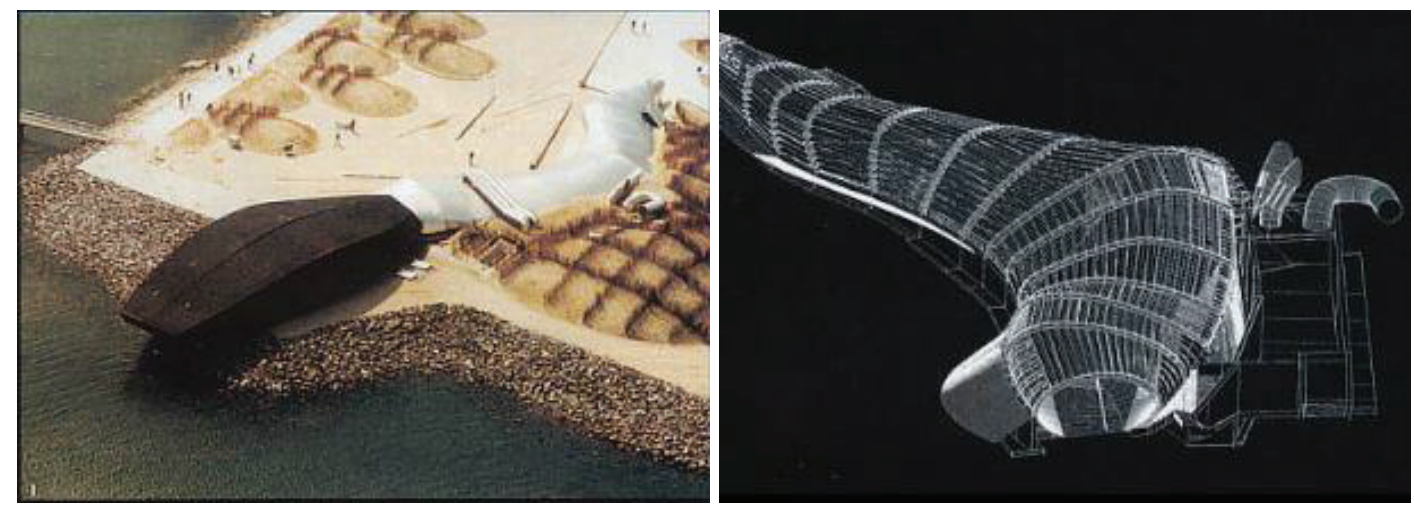

Figure 8. H2O Expo [14]

The first level of meaning of Figure 9 does not fit into the definition of a structure we know from our life experiences. For this first reading, it is necessary to know the starting point of the design and evaluate the concepts accordingly. The denotation level, which is an unencrypted visual message, refers to a "hybrid structure". In the second level of interpretation, the connotation level, the meanings to be given are reached by reading the messages that exist behind the visible. The most important level that allows the sign to gain meaning is the level of the connotation in which the concept gains metaphorical meaning. In order to make this interpretation, it is necessary to discuss the image by taking it over the signifier and signified. The signifier of this structure is the "shell form consisting of black and white forms" because it is the tangible (material) presence of the sign in the process of interpretation. In this process, the signifier does not gain a certain meaning and remains in the state of the object. In order for the signifier to bear value, the signified must be involved in the interpretation process. Since water is used as an object in the design, the signified in this structure is "liquid architecture". Thus, the signifier (shell form) gains expression with the help of the signifier and the structure gives the impression that it is part of the water. Based on all data, it is possible to evaluate the connotation level of this structure as "the relationship of the structure compared to the organism with the sea" (whale form). 


\begin{tabular}{|c|c|c|}
\hline $\begin{array}{l}\text { Sign: } \\
\text { H2O Expo Water Pavillion }\end{array}$ & First Level of Meaning: & Second Level of Meaning: \\
\hline $\begin{array}{l}\text { Signifier: } \\
\text { Shell form (forms of black } \\
\text { and white colors) }\end{array}$ & Unencrypted Image Plane & $\begin{array}{l}\text { Encrypted Image Plane } \\
\text { (Metaphoric Meaning) }\end{array}$ \\
\hline $\begin{array}{l}\text { Signified: } \\
\text { Liquid architecture }\end{array}$ & $\begin{array}{l}\text { * Denotation Level: } \\
\text { Structure with hybrid } \\
\text { features }\end{array}$ & $\begin{array}{l}\text { Structure water piece } \\
\text { that is likened to the } \\
\text { organism }\end{array}$ \\
\hline
\end{tabular}

Figure 9. H2O Expo Space Design (Produced by Author)

When we look at Figure 10, we notice that the unencrypted image plane (denotation level) defines the space used by individuals for visiting. In this context, it is possible to define the arrangement of this space as "social activity". Unlike the previous example, the boundaries between the virtual and the real environment disappear in the metaphorized interior. More specifically, in the design, the floors and walls come together to create wavy surfaces and the architectural elements are interacted and the space is liquefied. The connotation of the liquid architecture is reinforced in the encrypted image plane and a reference is made to the concept of "travel in space".

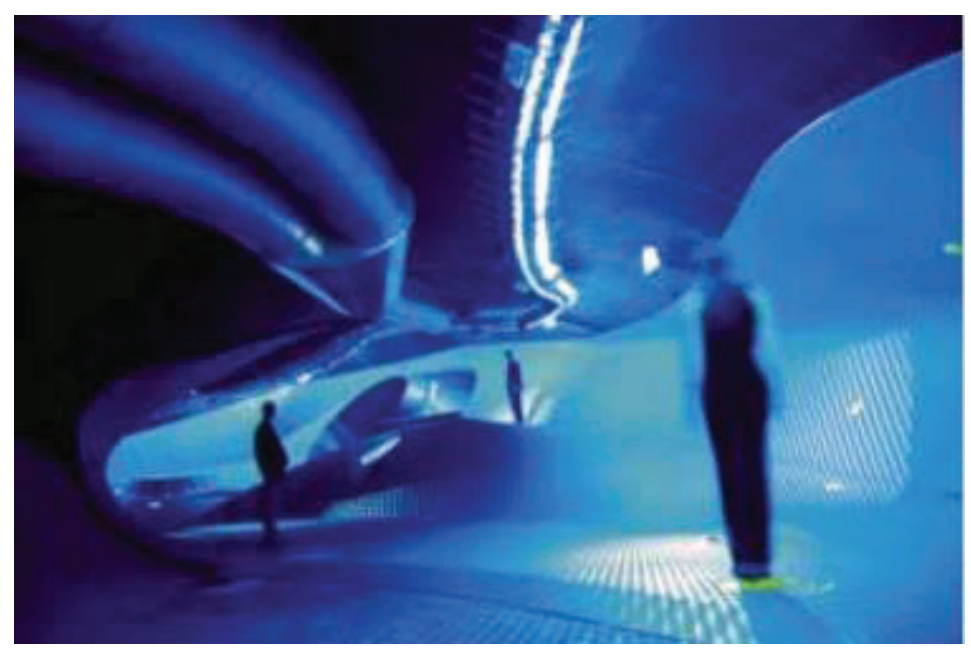

Figure 10. H2O Expo Space Design [15]

Another place addressed is the visiting area in Figure 11. Due to the curvilinear forms and fluidity shown in this space, the denotation level reflects the pure view of the solid space. On the other hand, the message of this place gives the feeling of not being understood enough for an individual who does not know the concept of the building. Since water is the main element of the design, fluidity is provided in the space and 
the natural environment is also felt inside. In order to be able to read the space by semiotic method, it is necessary to touch on the concept of syntax and system in this design. When we continue to read the image, the floor - wall - ceiling come together to reveal the syntax and these elements are located in a system and define the visit area.

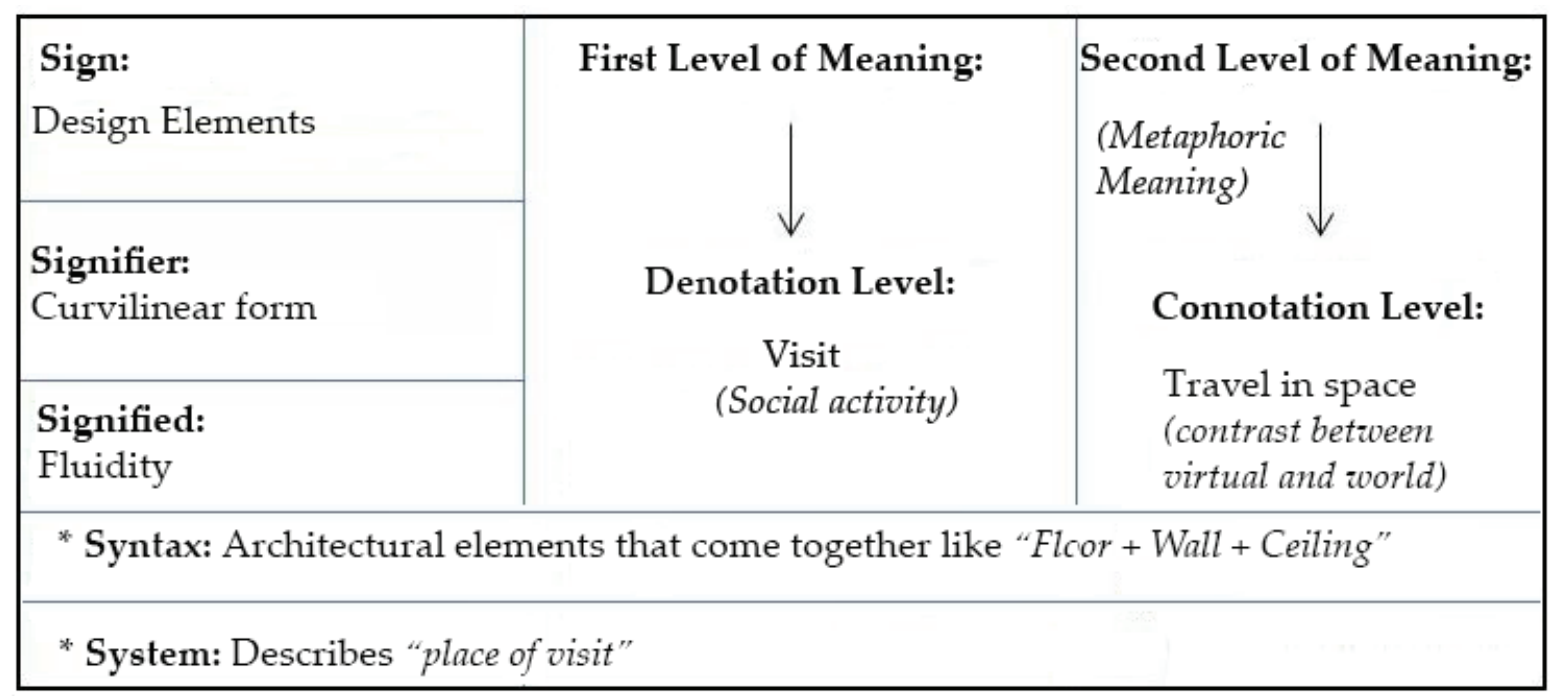

Figure 11. Denotation and Connotation Level of H2O Expo Space Design (Produced by Author)

Figure 12 shows the Winton Gallery designed by Zaha Hadid. The most important feature of the space, which is defined by emphasizing the importance of mathematics, is that it was designed by being inspired by the Handley Page plane. The interior of the building, which is defined as the exhibition hall, was designed with an approach based on change and technology. When using 3D curved forms, a perceptible space based on geometric forms has been created.

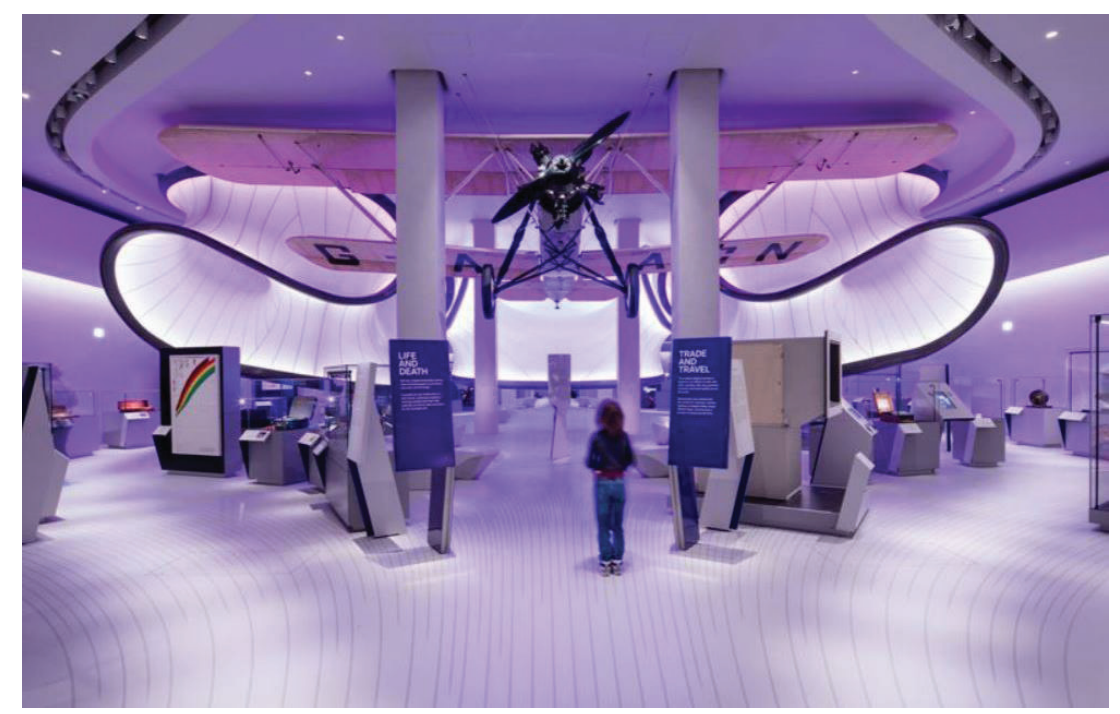

Figure 12. Winton Gallery [16] 
In Figure 13, while curvilinear forms reflecting the Handley Page plane are the signs of this space, the architectural elements designed by being affected by the plane in question are the visual messages. As we continue to read the picture, the "mobility" that represents the aircraft and continues in the interior is the general setup of the design. Therefore, while the denotation of the space is defined as the exhibition space, a reference is made to the Handley plane in a fluidity based on connotation math. The important point here is to create a sense of space that interacts with the next generations. In this framework, architectural elements that redefine the environment and represent technology are designed with a mathematical logic.

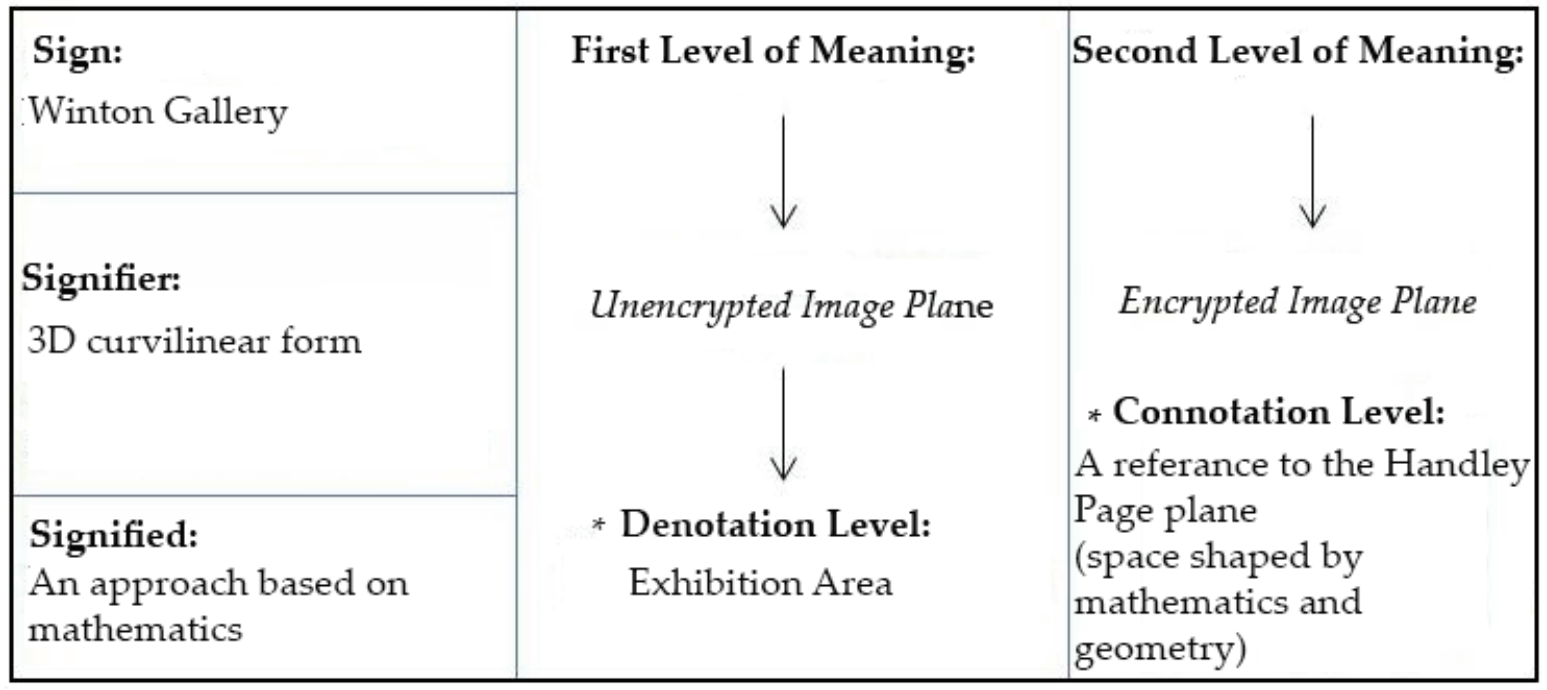

Figure 13. Winton Gallery denotation and connotation level (Produced by author)

Associating semiotics with architecture means taking the design process in a sense from a mental perspective. The fact that mental representations, attitudes that become behaviors by experience and individual and cultural information affect the design action by coding over time causes the concepts to be questioned from a different perspective. Especially when we examine the meaningful process of architectural products; the distinctive features of different periods and styles, different application prefixes reflecting the technological development of cultural differences, offer a wide range of work in semiotics.

\section{CONCLUSION}

In this study, a connection is established between architecture and semiotics and space reading is handled through semiotics concepts. Some determinations are made by examining two categories as signifier and signified. While basically the signifier is characterized as a concrete asset, the signified is defined as the meaning and thought desired to be given. Therefore, it is a message operation that an entity displayed in the semiotics method refers to. On the other hand, the clustering process created to create a whole from a paradigm is called system. For example, furniture such as "bed-wardrobe-table" combined to design a space characterizes a system and it is possible for this functionally compatible furniture to work in harmony. The first meaning (denotation) level and the second meaning level (connotation) that enable communication between the receiver and the sender have an important place in the basic reading principle of the space. While connotation is the first image of an entity to come to life in our minds, it is a state of metaphoric character. In other words, connotation is accepted as the basic level of the process of interpretation, since it refers to a solid entity. 
When we examine the semantics model of meaning, we encounter leading names such as Charles Sanders Peirce and Ferdinand de Saussure. Considering the research of these names, Peirce semiotics builds up on the three-plane "sign / object / interpreter" relationship, while Saussure classifies this field in a binary structure as "concept" and "communication image". The important point here is that Peirce examines the connection between the sign and the object in line with individual and cultural information; it is Saussure's evaluation of the emergence of a concept in a mental process. Therefore, Saussure builds the receiversender relationship on the linguistic sign. The sender creates sound waves to express the mental concept, while the receiver understands and responds to the sound waves.

Based on all these data, when we read the space with semiotics method, design is evaluated based on the perception of form. While the architectural elements are handled through the sign-signifier-signified, the message (reference made to an asset) desired in the interior is sought in the connotation level. For example, $\mathrm{H} 2 \mathrm{O}$ Expo Water Pavilion and Winton Gallery produce a language tool in communication studies in terms of the meanings it contains. When both designs are based on semiotics, it is seen that their metaphorical meanings evoke different concepts. In line with this information, while $\mathrm{H} 2 \mathrm{O}$ Expo Water Pavilion was a design based on the concept of liquid architecture, it was tried to be examined with the semiotics method, which is the reference made to Winton Gallery, which is shaped by mathematics and geometry, to an airplane.

\section{REFERENCES}

[1] Erkman Akerson, F. (2005). Göstergebilime Giriş. İstanbul: Multilingual. Erkman-Akerson, F. (2005). Göstergebilime Giriş. 1. Bask1. İstanbul: Multilingual. Günay, D.(2007). Metin Bilgisi, 3.

[2] Barthes, R. (2014). Göstergebilimsel Serüven, (Mehmet Rıfat ve Sema Rıfat Çev.), İstanbul: YKY.

[3] Mutlu, E. (2017). İletişim Sözlüğü. Ankara: Ütopya Yayınevi.

[4] Guiraud, P. (1994). Göstergebilim. (2. Bask1). Çev. Mehmet Yalçın, Ankara: İmge Kitabevi Yayınları. [5] Rıfat, M. (1986). Genel Göstergebilim Sorunları Kuram ve Uygulama, İstanbul: Sözce Yayınları.

[6] Atabek, G. Ş. ve Atabek, Ü. (2007). "Medya Metinlerini Çözümlemek”. Iç̧erik, Göstergebilim ve Söylem Çözümleme Yöntemleri, Ankara: Siyasal Kitabevi.

[7] Barthes, R. (2014). “Çağdaş Söylenler”. Günümüzde Söylen. (4. Bask1). Çev. Tahsin Yücel, İstanbul: Metis Yayınları.

[8]. Barthes, R. (1979). Göstergebilim Illkeleri. Çev. Berke Vardar ve Mehmet Rifat, Ankara: Kültür Bakanlığı Yayınları.

[9] Fiske, J. (2014). Illetişim Çalışmalarına Giriş. (3. Basım). Çev. Süleyman İrvan, Ankara: Pharmakon Yayınevi.

[10] Rıfat, M. (2005). XX Yüzyılda Dilbilim ve Göstergebilim Kuramları 2 Temel Metinler. (2. Bask1). İstanbul: YKY.

[11] Rıfat, M. (2009). Göstergebilimin ABC'si. (3. Bask1). İstanbul: Say Yayınları.

[12] Rıfat, M. (2000). XX. Yüzyılda Dilbilim ve Göstergebilim Kuramları 1: Tarihçe ve Eleştirel Düşünceler, (2. Bask1). İstanbul: OM Yayınevi.

[13] Saussure F. (2001). Genel Dilbilim Dersleri. Çev. Berke Vardar, İstanbul: Multilingual.

[14] http://spazioinwind.libero.it/nicolafariello/prog.arc.ass/www/esame/h2o.html, (last accessed on 08 July 2019)

[15] http://www.archilab.org/public/1999/artistes/noxa01en.htm\#, (last accessed on 08 July 2019)

[16] https://www.arkitektuel.com/winton-galerisi/\#jp-carousel-7785, (last accessed on 08 July 2019) 
GAMZE AKBAŞ, Lecturer

She was born in 1987 in Ankara. She is working as a lecturer in the Department of Interior Architecture and Environmental Design at Istanbul Kültür University. Between 2007 and 2012, she studied at the European University of Lefke, Faculty of Architecture and Engineering, Department of Interior Architecture. In 2015, she completed her master's degree at At1lim University, Institute of Social Sciences, Department of Interior Architecture and Environmental Design. Her master thesis is on the "Traditional Construction Techniques and Space Relations: Uzungöl and Taşkıran Examples". She is currently a PhD candidate at Çankaya University, Architecture Programme. 